\title{
Značenje Atlasa svijeta Leksikografskoga zavoda Miroslav Krleža u hrvatskoj atlasnoj kartografiji
}

\author{
Ivana Crljenko ${ }^{\circ}$ \\ Leksikografski zavod Miroslav Krleža, Zagreb \\ ivana.crljenko@lzmk.hr
}

SAŽETAK: Leksikografski zavod Miroslav Krleža objavljuje geografske atlase opće namjene od 1960-ih. Najzapaženiji je Atlas svijeta objavljen u sedam izdanja, pod vodstvom više glavnih redaktora/urednika, koji su uglavnom zadržali početnu koncepciju atlasa, ali su unijeli nove uredničke ideje i stilove. Jedini je potpuno domaći atlas svijeta, komercijalno među najuspješnijim zavodskim izdanjima i jedan od najraširenijih atlasnih priručnika u Hrvatskoj. Pretpostavlja se stoga da je njegovo značenje u ukupnoj produkciji geografskih atlasa svijeta u Hrvatskoj iznimno. Svrha rada jest pokazati je li ta pretpostavka opravdana. Napravljeno je istraživanje u kojem se analizom nekih obilježja (ideja, posebnosti, struktura atlasa i poglavlja, karte, pristupi, stil pisanja) zavodskoga i odabranih prijevodnih atlasa svijeta u razdoblju od tiskanja prvoga (1961) do posljednjega zavodskoga atlasa (2008) te njihovom usporedbom dolazi do ciljeva istraživanja: a) raspoznavanje sličnosti i razlika (posebnosti) zavodskoga atlasa u odnosu na atlase drugih nakladnika, b) ocjena utjecaja koje zavodski atlas ima u širenju geografskih znanja, c) određivanje njegova značenja u hrvatskoj atlasnoj kartografiji. Rezultati istraživanja upućuju na iznimno značenje zavodskoga atlasa koje proizlazi iz njegovih posebnosti. Ističe se jer prikazuje svijet iz domaće perspektive, odražava visoku stručnost u obradi sadržaja primjenom načela obuhvatnosti i dosljednosti, sadržava pojačanu tekstualnu sastavnicu, postavlja norme u pisanju geografskih imena iz stranih jezika, predočuje vlastite karte i primjenjuje leksikografski stil pisanja.

Ključne riječi: atlasi svijeta; Leksikografski zavod Miroslav Krleža; karte; toponimi

\section{Uvod}

Kartografski prilozi različite tematike, sadržaja i obuhvata prostorne stvarnosti oduvijek su bili nezaobilazna popratna sastavnica prevladavajuće tekstualnih enciklopedijskih i leksikonskih zavodskih izdanja. Pojavljuju se najčešće kako bi vizualno upotpunili informacije o najvećim i/ili najvažnijim geografskim objektima. Njihova je zastupljenost znatno veća u atlasima i vodičima - primarno kartografsko-geografskim izdanjima koja se zasnivaju na vizualizaciji prostornih podataka - pa su takva

(D) https://orcid.org/0000-0002-1315-0644 [Ivana Crljenko] 
izdanja bogato opremljena kartama, fotografijama, crtežima, skicama, tablicama, dijagramima, grafikonima i sl. U njima su upravo karte temeljna sastavnica izdanja, tj. osnovni nositelji podataka, pa su prema zamišljenoj hijerarhiji važnosti izražajnih sredstava kartografski prilozi u atlasima i vodičima jednakovrijedni ili nadređeni tekstualnim dijelovima.

Kartografska izdanja u sadržajnom su smislu primano geografska - rjeđe i povijesna, zoološka ili neka druga ako je, primjerice, riječ o povijesnom, zoološkom ili drugom atlasu - što zbog očite i dugotrajne povezanosti kartografije i geografije ne čudi. U praksi to znači da ih izrađuju kartografi i geografi. Posve je logično stoga da su se najprije kartografi (crtači, tj. grafičari zaduženi za tehničku izvedbu i obradu karte), a poslije i geografi, okupili u posebnoj zavodskoj radnoj jedinici - Kartografskom odjelu (poslije Kartografskoj redakciji) - već u samom počeku rada Zavoda, od 1950. Zbog opsežnog rada na enciklopedijskim izdanjima - Pomorskoj enciklopediji, Enciklopediji fugoslavije, Enciklopediji $\mathcal{Y} L Z$ - a - i na posebnom atlasnom izdanju, u drugoj polovici 1950-ih u Kartografski su se odjel primali novi zaposlenici pa je u to doba u njemu radilo desetak kartografa. Broj im se povećao potkraj 1980-ih, kada ih je bilo najviše (čak 20-ak!). Od 1970-ih pridružuju im se geografi, koji su uglavnom bili urednici zaduženi za osmišljavanje i stručnu utemeljenost sadržaja na kartama (Klemenčić, Richter-Novosel 2001; Klemenčić, Richter-Novosel 2008). Sa znatno smanjenim brojem zaposlenih u redakciji zbog prelaska na računalnu kartografiju, kao i reduciranog broja izdanja u kojima se informacije prenose i kartografskim prilozima, takva je kadrovska politika kartografa-crtača i geografa-urednika u Zavodu ostala do danas.

Kao rezultat rada zaposlenika u Kartografskom odjelu - osobito njegova osnivača i prvoga voditelja Petra Mardešića - koji su za potrebe rada na prvim enciklopedijama prikupili i izradili brojne karte kontinenata, država i skupina država te tako stvorili dostatnu bazu kartografskih priloga za posebno atlasno izdanje (Klemenčić, Richter-Novosel 2001; Klemenčić, Richter-Novosel 2008), po uzoru na ranija izdanja Geografskog atlasa u nakladi Seljačke sloge (od 1958. Znanje) (Klemenčić 2013), 1961. tiskano je prvo izdanje zavodskoga geografskoga atlasa svijeta opće namjene, jednostavno naslovljeno Atlas svijeta. ${ }^{1}$ Otada je objavljeno sedam izdanja tog

1 Osim Atlasa svijeta, Zavod je iznjedrio brojne geografske atlase, vodiče, autoatlase te turističke i cestovne karte, od kojih su mnogi izišli u više izdanja i/ili na više jezika (više u: Klobučar Srbić 2012). Od geografskih atlasa iz 1990-ih posebno se ističu A Concise Atlas of the Republic of Croatia and the Republic of Bosnia and Hercegovina (1993) i Atlas Europe (1997). Prvi je tiskan na engleskom jeziku kako bi se stranim korisnicima omogućilo valjano upoznavanje s geografskim obilježjima i sažetim povijesnim razvojem mladih europskih država - Hrvatske i BiH. Drugi i mnogo opsežniji je enciklopedijski Atlas Europe, koji je izrađen kako bi se premostila praznina u razmjerno redovitom tiskanju Atlasa svijeta. Naime, ${ }^{6} \mathrm{AS}$ objavljen je neposredno prije političkih promjena 1989. i 1990-ih pa je vrlo brzo zastario. Budući da se većina promjena dogodila u Europi, izrada Atlasa Europe bila je logično rješenje. Taj popu- 
atlasa pod vodstvom više glavnih redaktora/urednika: ${ }^{1} 1961$. ('AS, 506 str.), ${ }^{2} 1963$. ( ${ }^{2} \mathrm{AS}, 543$ str.), ${ }^{3}$ 1966. ( ${ }^{3} \mathrm{AS}, 550$ str.) i ${ }^{4} 1969$. ( ${ }^{4} \mathrm{AS}, 603$ str.) pod redaktorskim palicama Petra Mardešića i Ote Oppitza, ${ }^{5}$ 1974. ( ${ }^{5} \mathrm{AS}, 602$ str.) pod vodstvom Ote Oppitza, ${ }^{6}$ 1988. ( ${ }^{6} \mathrm{AS}, 955$ str.) uz urednički rad Božidara Feldbauera i ${ }^{7} 2006$. ( ${ }^{7} \mathrm{AS}, 871$ str.; i 2008. s ponovljenim, malo izmijenjenim ${ }^{7}$ AS) s Mladenom Klemenčićem kao glavnim urednikom. ${ }^{2}$ Tiskanje novih atlasa bilo je najdinamičnije 1960-ih, što je rezultat tadašnjih čestih promjena u političkoj karti svijeta. U 1960-ima kao izravna posljedica dekolonizacije nastalo je 30-ak država. Tako su u vrijeme tiskanja ${ }^{1} \mathrm{AS}$ u svijetu bile 123 neovisne države ( $\left.{ }^{7} \mathrm{AS}, \mathrm{I}\right)$. I ${ }^{5} \mathrm{AS}$ tiskan je razmjerno brzo nakon ${ }^{4} \mathrm{AS}$ jer je u međuvremenu nastalo još šest država. Veće su se promjene dogodile i u 1990-ima kao posljedica pada socijalizma i raspada višenacionalnih država na 20 -ak novih. U vrijeme tiskanja ${ }^{7} \mathrm{AS}$ bilo je 198 neovisnih država i djelomično priznatih područja. Budući da su države temeljne jedinice obrade, s povećanjem njihova broja u svakom se sljedećem izdanju uglavnom povećavao i broj karata, kao i ostali tekstualni i grafički sadržaji o novim državama.

O Atlasu svijeta u literaturi se govori kao o najzapaženijem zavodskom atlasu, ${ }^{3}$ o atlasu koji je prvi i jedini potpuno domaći atlas svijeta u Hrvatskoj s autentičnim pogledom na svijet, o atlasu koji je količinom ponuđenih informacija bio bez premca u nas, o jednom od najraširenijih atlasnih priručnika u Hrvatskoj, o izdanju koje je komercijalno među najuspješnijim zavodskim izdanjima (Klemenčić, Richter-Novosel 2001; Klemenčić /ur./, 2006; Klemenčić, Richter-Novosel 2008; Klemenčić 2013). U prilog potonjem idu podatci o nakladi i prodanim primjercima. Ukupna naklada ${ }^{1}$ AS- ${ }^{5}$ AS iznosila je čak 145 000, odnosno 165000 primjeraka (Klemenčić, Nikolić 1987; Feletar 1989). Rasprodana su i posljednja dva atlasa - ${ }^{6}$ AS u nakladi od 8500 primjeraka (Feletar 1989) i ${ }^{7} \mathrm{AS}$ u nakladi od 2000 primjeraka (Klemenčić, Richter-Novosel 2008) pa je 2008. tiskan ponovljeni ${ }^{7} \mathrm{AS}$.

Iz navedenoga proizlazi pretpostavka da je značenje zavodskoga Atlasa svijeta u hrvatskoj atlasnoj kartografiji iznimno. Svrha je ovoga rada pokazati je li ta pretpostavka opravdana. Postavljena su tri cilja istraživanja: a) raspoznavanje sličnosti i razlika (posebnosti) zavodskih atlasa u odnosu na atlase drugih nakladnika, b) ocjena utjecaja koje zavodski atlasi imaju u širenju geografskih znanja (jer su atlasi svijeta

larni atlas unio je neke koncepcijske novine, koje se očituju u opsežnijoj tekstualnoj obradi država i Europe te u povećanoj kartografskoj zbirci u odnosu na onu iz ${ }^{6}$ AS (Klemenčić 1993; Jordan 1995; Richter 1996; Klemenčić, Richter-Novosel 2001; Klemenčić, Richter-Novosel 2008).

2 S obzirom na različite urednike, izdanja se stilski, više nego koncepcijski, bitno razlikuju. Zato se o zavodskom atlasu u radu govori u množini (»zavodski atlasi svijeta«); rabe se kratice s oznakom izdanja ( ${ }^{1} \mathrm{AS}$ do $\left.{ }^{7} \mathrm{AS}\right)$. I za druge se atlase upotrebljavaju kratice (npr. ZA85, VOAS04).

3 U radu se analiziraju geografski atlasi svijeta pa se radi pojednostavljenja u daljnjem tekstu upotrebljavaju termini »atlasi svijeta« ili »atlasi« umjesto »geografski atlasi svijeta«. 
ponajprije kartografsko-geografska djela), te c) određivanje njihova značenja u hrvatskoj atlasnoj kartografiji. Korištena je metoda usporedbe atlasa svijeta opće namjene (dakle, ne školskih) objavljenih u Hrvatskoj u razdoblju od tiskanja prvoga zavodskoga atlasa (1961) do posljednjega (2008; iste godine tiskan je i posljednji nezavodski atlas). Za valjanu usporedbu analizirani su svi zavodski atlasi i deset najopsežnijih atlasa drugih nakladnika u nekoliko kategorija. $U$ radu se pojedinačno predstavljaju kategorije: a) ideja atlasa (potreba, svrha, poticaji), b) posebnosti (ili novine u zavodskim atlasima) c) mjerila geografskih karata, ${ }^{4}$ d) struktura atlasa i veća poglavlja ${ }^{5}$ (s brojem stranica u zagradi i, ako je potrebno, kratkim opisom poglavlja). Skupno se predstavljaju kategorije: e) izražajna sredstva, f) predočivanje reljefa i kartografski znakovi na geografskim kartama, g) tematske karte, h) toponimi, i) pristup u obradi tekstualnih sadržaja, j) pristup u koncepciji, k) stil (način) pisanja. Prvih pet zavodskim atlasa zbog sličnosti analizira se skupno. U sintezi se donose zajednička obilježja svih atlasa i posebnosti zavodskih, čime se odgovara na istraživačko pitanje: Kakvo je značenje zavodskih atlasa svijeta u hrvatskoj atlasnoj kartografiji i u čemu se očituje?

\section{Zavodski atlasi svijeta}

Ideja zavodskih atlasa istaknuta je u predgovoru ${ }^{1} \mathrm{AS}$ (VII). Redaktori navode tri glavna poticaja objavljivanja atlasa: a) dekolonizacija i stvaranje novih neovisnih država u Aziji i Africi, što se naglašava definiranjem atlasa kao »geografsko-političkog vodiča $u$ u vremenu brzih promjena političke karte svijeta, b) stvaranje novog socijalističkog poretka kao »državne organizirane snage« nasuprot izlomljenim »elementima kapitalističke ekonomike«, c) razvoj prometa, osobito telekomunikacija, i učinci tog razvoja na širenje znanja i informacija. Smatraju da je »potrebno povezivanje čitave Zemlje kao političke i kulturne pozornice na kojoj se rješava sudbina svega što su čovjeku namrla pokoljenja i što on danas stvara kao svjedočanstvo svoje visoke tehničke i moralne svijesti«. Zaključuju stoga da je »potreba za ovom vrstom geografsko-političkog i geografskog priručnika očigledna«. Želja im je da on bude informativan i pouzdan. U ${ }^{6} \mathrm{AS}$ (VII) naglašava se da osim što udovoljava općenitom zahtjevu atlasa - da je zbirka karata - Atlas svijeta je i svojevrsni pregled država.

4 »Geografske karte« pojednostavljeni je naziv za topografske karte krupnih mjerila (1:500 000 i krupnije) i geografske pregledne ili korografske karte, tj. topografske karte sitnih mjerila (1:500 $000 \mathrm{i}$ sitnije). Na njima su predočena prirodna i društvena obilježja prostora. Ponekad se nazivaju fizičkim kartama. Ovdje se rabi pojam geografske karte jer je većina karata u atlasima svijeta sitnog mjerila, dakle, to su geografske pregledne karte.

5 Ne navode se kraća uvodna (o atlasu i kartama) i završna poglavlja karakteristična za sva ili većinu izdanja, poput predgovora, sadržaja, tumača znakova, uputa za korištenje, popisa kratica, mjernih jedinica, zastava, geografskih karata, literature i dr. Naslovi poglavlja su opisni, dakle ne podudaraju se nužno s naslovima u atlasima. 


\subsection{Prvih pet Atlasa svijeta ( $\left({ }^{1} \mathrm{AS}-{ }^{5} \mathrm{AS}\right)$}

Budući da je prva četiri atlasa vodio isti redaktorski dvojac - Petar Mardešić i Oto Oppitz - a peti je nastavio uređivati Oppitz, prvih pet Atlasa svijeta imaju mnoge sličnosti. Svaki je novi atlas donosio manje novine, ispravke, osvježavanja i dopune »tako da prikazuje najnovije političko i ekonomsko stanje u svijetu« ( ${ }^{3} \mathrm{AS},{ }^{4} \mathrm{AS},{ }^{5} \mathrm{AS}$, 7), ali osnovna koncepcija ostala je ista. Zato se pojedinačne analize atlasa ovdje predstavljaju skupno.

Svim je atlasima zajedničko da su opsegom veći u odnosu na prijašnje izdanje. Od ${ }^{1} \mathrm{AS}$ do ${ }^{5} \mathrm{AS}$ broj stranica povećavan je za oko 100, što je posljedica povećanja svih dijelova atlasa. Proširivanje tekstualnoga dijela ponajviše je rezultat dopunjavanja u poglavljima koji obrađuju Jugoslaviju i druge države (broj kojih se s vremenom povećavao). U ${ }^{2}$ AS tekstualni dio proširen je s oko 100 skica. Proširivanjem kartografskoga bloka novim kartama povećao se i popis geografskih imena.

Koncepcija atlasa s trima osnovnim dijelovima (tekstualni, kartografski i popisni) i struktura poglavlja u svim atlasima uglavnom su ujednačeni. U nekima su promijenjeni naslovi poglavlja, ali je sadržaj ostao isti; negdje je sadržaj dopunjen (npr. Međunarodne organizacije). Struktura:

- O postanku i prirodi svemira (11-19)

Podatci o postanku svemira, zvijezdama, galaksijama, Sunčevu sustavu, Zemlji i gibanjima Zemlje, Mjesecu te strukturi Zemlje.

- $\quad$ Svijet (19-22)

Statistički prikaz (s tablicama i skicama) Zemlje, kontinenata, mora, otoka, jezera, rijeka, planina, potresa, vulkana, stanovnika, gradova, poljoprivredne proizvodnje, energenata i dr.

- Ujedinjeni narodi (u ${ }^{4}$ AS i ${ }^{5}$ AS Međunarodne organizacije) (2-8)

Pregled Ujedinjenih naroda i njegove strukture. U ${ }^{4} \mathrm{AS}$ i ${ }^{5} \mathrm{AS}$ i drugih organizacija po kontinentima.

- Jugoslavija (17-29)

Opis Jugoslavije. Sastoji se od tekstualnoga (građa i reljef, klima, vode, bilini pokrov, stanovništvo, državno uređenje, ustav) i statističkoga dijela (državne granice, najveće planine, otoci, rijeke, kanali, jezera, stanovništvo, upravna podjela, poljoprivredna i industrijska proizvodnja, energenti, prometnice, promet putnika, mornarica, institucije i dr.). Dopunjavan je tablicama i detaljnijim crno-bijelim kartografskim prikazima; ažuriran je podatcima popisne statistike. 
- $\quad$ Ostale zemlje i kontinenti (155-235)

Pregled ostalih neovisnih i ovisnih zemalja te kontinenata po abecednom redu (reljef i građa, klima, vode, biljni pokrov, stanovništvo, državno uređenje, predsjednik, administrativna podjela, glavni grad, ponegdje i drugi veći gradovi, privreda, trgovina, promet, novac). Dopunjavan je tablicama, manjim crno-bijelim tematskim kartama ili planovima u gotovo svim državama.

- Indeks teksta (5)

Od ${ }^{2} \mathrm{AS}$ dodano je kazalo pojmova iz tekstualnoga dijela.

- $\quad$ Karte (197-168)

$\mathrm{U}^{1} \mathrm{AS}$ je 90 geografskih karata i 64 tematskih. ${ }^{6} \mathrm{U}^{2} \mathrm{AS} \mathrm{S}^{7} \mathrm{i}^{3} \mathrm{AS}$ je 95 geografskih i 39 tematskih karata. U ${ }^{4} \mathrm{AS}$ je 148 stranica s »političkim» kartama te 22 stranice s tematskim kartama. U ${ }^{5} \mathrm{AS}$ je 138 »političkih» karata i 20 tematskih karata. Smanjenjem broja tematskih karata smanjuje se i ukupan broj stranica kartografskoga bloka.

- Indeks geografskih imena (od ${ }^{2}$ AS Popis geografskih imena) (90-102)

Sadržava oko 51000 toponima u ${ }^{1} \mathrm{AS}, 60000$ toponima u ${ }^{2} \mathrm{AS}$ i ${ }^{3} \mathrm{AS}$, te 90000 toponima u ${ }^{4} \mathrm{AS}$ i ${ }^{5} \mathrm{AS}$.

\section{2. Šesti Atlas svijeta ( $\left.{ }^{6} \mathrm{AS}\right)$}

Četrnaest godina nakon ${ }^{5} \mathrm{AS}$ objavljen je ${ }^{6} \mathrm{AS}$ glavnoga urednika Božidara Feldbauera. Novi urednik unio je mnoge novine, koje se očituju »u povećanu opsegu, s proširenim i obnovljenim sadržajem« ( $\left.{ }^{6} \mathrm{AS}, \mathrm{VII}\right)$ te u likovno-grafičkom preoblikovanju. Znatno je povećan broj stranica (za oko 350), kao i broj poglavlja. Novine u tekstualnom dijelu najviše se odnose na uvođenje novih sadržaja u obradi država (povijest, geopolitički položaj, položajna karta, grb i zastava), a u poglavljima o Jugoslaviji na proširenje sadržaja (bitno su dopunjeni dijelovi o stanovništvu i društveno-političkom uređenju) i strukture (dodana su poglavlja: povijesni razvoj po republikama, geopolitički položaj i društveno-ekonomski razvoj). Tekstualni dio ima i 1176 ilustracija. Izrađene su nove tematske karte (npr. geopolitičke) i dodane su nove fotografije.

${ }^{6}$ Na nekim je stranicama više tematskih karata, dok su neke karte dvostranične ili preklopne pa broj stranica s kartama ne odgovara broju karata.

7 Iz ${ }^{2}$ AS (7): »U drugom izdanju Atlasa izostavljene su primijenjene (tematske, op.a.) karte pojedinih kontinenata, ali su proširene primijenjene karte svijeta; dodani su pregledni listovi koji pokazuju raspored fizičkih (geografskih, op.a.) karata za svaki kontinent posebno«. 
Atlas se sastoji od triju dijelova: tekstualnoga, kartografskoga i popisnoga. Struktura:

- O postanku i prirodi svemira (4)

- Postanak i razvoj Sunčeva sustava (6)

- Zemlja (35)

Podatci (osobito o ekstremima) o Mjesecu, strukturi i dinamici Zemlje, morima, rijekama, jezerima, atmosferi, klimi i stanovništvu sa skicama, tablicama, tematskim kartama i satelitskim snimkama.

- Međunarodne organizacije (9)

Pregled najvažnijih međunarodnih organizacija, najviše o Ujedinjenim narodima.

- $\quad$ Nesvrstanost (2)

Pregled politike nesvrstanih; članice.

- $\quad$ Pregled svjetske privrede (43)

Statistički prikaz (s tematskim kartama i tablicama) poljoprivredne proizvodnje, energenata, ruda i dr.

- Jugoslavija (91)

Opis geografskoga i sažetoga povijesnoga razvoja Jugoslavije. Jedan je od najdetaljnijih tadašnjih statističkih pregleda Jugoslavije uopće. Sastoji se od tekstualnoga (smještaj, položaj, granice, reljef, građa, vode, klima, vegetacijski pokrov, stanovništvo, naselja, društveno-političko uređenje, povijesni razvoj, geopolitički položaj i društveno-ekonomski razvoj) i statističkoga dijela (planinski vrhovi, potresi, klima, otoci, rijeke, jezera, nacionalni parkovi, stanovništvo, gradovi, poljoprivredna i industrijska proizvodnja, energenti, prometnice, promet putnika, turizam, institucije i dr.). Statistički podatci najčešće su prikazani tablično.

- $\quad$ Ostale države i kontinenti (457)

Pregled ostalih neovisnih i ovisnih zemalja i kontinenata po abecednom redu (prirodna osnova, stanovništvo, povijest, državno uređenje, geopolitički položaj/ponegdje/, privreda). Tablično je prikazana upravna podjela s većim gradovima te vanjska trgovina (ponegdje i klimatski podatci), kartogramom gustoća naseljenosti, tematskim kartama gospodarstvo i geopolitički položaj.

- Tumač uz geopolitičke priloge (2)

Rječnik najvažnijih geopolitičkih pojmova. 
- Rječnik geografskih pojmova (14)

- $\quad$ Karte (168)

Kartografski blok obuhvaća 103 geografske karte i 26 tematskih karata svijeta i Europe.

- Popis geografskih imena (109)

Sadržava 59237 toponima.

\subsection{Sedmi Atlas svijeta ( $\left.{ }^{7} \mathrm{AS}\right)$}

Gotovo dvadeset godina nakon ${ }^{6} \mathrm{AS}$, preciznije 2006. (i 2008) objavljen je ${ }^{7} \mathrm{AS}$, koji je uredio Mladen Klemenčić. I taj je atlas donio mnoge novine, ponajviše u koncepciji atlasa i strukturi poglavlja te opsegu tekstualnoga dijela. Nema uvodnoga dijela o svemiru, Sunčevu sustavu i Zemlji (što je slučaj i u drugim novijim atlasima). Države se obrađuju abecedno po kontinentima, koji su koncepcijski smješteni ispred pripadnih država, a ne zajedno s njima. To je pospješilo preglednost, sistematičnost i pretraživost tekstualnoga dijela. Za razliku od ranijih atlasa u kojima je Jugoslavija obrađena u posebnom, opširnijem poglavlju, u ${ }^{7}$ AS Hrvatska zauzima pet stranica, što je tek nešto više od drugih država njezine veličine i značenja (npr. Irska i BiH obrađene su na četiri stranice, Italija na šest stranica). Izuzimanjem pojačane nacionalne sastavnice Atlas je postao općenitiji od prijašnjih. Tekstovi su sažetiji, osobito u dijelu o gospodarstvu. Smanjen je broj karata (90-ak), poglavlja i stranica atlasa, ali je bolja opremljenost ilustracijama, osobito fotografijama. Novina su i promjene u kartografskom načinu rada, koji je s tradicionalne, crtačke tehnike prešao na računalnu. To je djelomično razlog prilično dugom razdoblju između tiskanja ${ }^{6} \mathrm{AS}$ i ${ }^{7} \mathrm{AS}\left({ }^{7} \mathrm{AS}, \mathrm{I}\right)$. Struktura:

Atlas se sastoji od triju dijelova: tekstualnoga, kartografskoga i popisnoga.

- $\quad$ Svijet (10)

Opisana je politička karta svijeta i Ujedinjeni narodi. U poglavlju su brojne tematske karte, tablice i fotografije.

- Europa*(188)

- Azija*(139)

- Afrika*(140)

- Amerika*(107)

- Australija i Oceanija*(35)

- Antarktika (1) 
- Zemljovidi (129)

Sadržava 96 karata s preglednim listovima i popisom geografskih karata. Karte su svrstane po kontinentima.

- Kazalo imena sa zemljovida (101)

Sadržava 47000 toponima.

Pregled kontinenata i država po abecednom redu (*) obuhvaća sljedeće dijelove: opći podatci, državni simboli, prirodna obilježja (smještaj, reljef, klima, vode, vegetacija), stanovništvo (demografska i kulturna obilježja), gospodarstvo (bruto domaći proizvod, nezaposlenost, ekonomski odnosi s inozemstvom, financije, opća obilježja), povijest (naglasak je na XX. st.). Obavezni prilozi su: zastava, grb, geografska karta, karta administrativne podjele, tablica upravne podjele, a česte su fotografije.

Kartografski prikazi u zavodskim atlasima izdvojeni su u posebnom bloku/poglavlju, a dijele se u dvije skupine: a) geografske karte kontinenata, država, dijelova ili skupina država i oceana ( ${ }^{4} \mathrm{AS} \mathrm{i}^{5} \mathrm{AS}$ to su »političke« karte), b) tematske karte svijeta, Europe i u prvih pet atlasa Jugoslavije. Obavezan dio je tumač znakova na posebnoj stranici. Kartografski dio atlasa s vremenom je doživio značajne promjene, ponajviše u broju karata. Nastankom novih neovisnih država, poglavito u 1960-ima, u svakom sljedećem atlasu ukupan se broj karata povećavao, da bi se u ${ }^{7} \mathrm{AS}$, ponajviše zbog reduciranih tematskih karata, broj karata smanjio.

Promjene su zabilježene i u izgledu i s tim povezanom nazivu geografskih karata. Uklanjanjem boja za predočivanje reljefa, kojima se uz sjenčanje služilo u svim atlasima, $u^{4} \mathrm{AS} \mathrm{i}^{5} \mathrm{AS}$ geografske karte nazvane su »političkim « kartama. ${ }^{8}$ Reljef se na njima prikazivao samo sjenčanjem, a boje su rabljene samo kako bi se istaknule obale i kopnene državne granice, rjeđe i granice administrativnih jedinica. Da nije riječ o pravim političkim kartama upućuje činjenica da su sadržaji na njima ostali isti kao na geografskim kartama prethodnih atlasa. Naime, nisu se unosili specifično političko-geografski elementi i pripadni znakovi, već su samo naglašene postojeće granice. Također, nisu se ispustili nepotrebni sadržaji, poput sjena za prikaz reljefa. Mjerila karata ostala su nepromijenjena (osim rijetkih novih karata krupnijih mjerila). Boje su vraćene u ${ }^{6} \mathrm{AS}$ pa se otada ponovno govori o geografskim kartama.

8 U predgovoru ${ }^{5} \mathrm{AS}(7)$ ipak se ne spominju »političke« karte, nego samo karte, ali riječ je o »političkim« kartama iz ${ }^{4} \mathrm{AS}$. 
Geografske/»političke« karte u prvih pet atlasa izrađene su u mjerilima 1: 90000000 (svijet) do 1: 900000 (Crna Gora), a u ${ }^{6}$ AS 1: 90000000 (svijet) do 1 : 300000 (Malta) i krupnije (npr. karte Bospora, Gibraltarskih vrata). U ${ }^{7} \mathrm{AS}$ karte su izrađene u mjerilima 1:90000 000 (svijet) do 1:1 000000 (Hrvatska u dijelovima). Uz rub nekih karata dodane su karte krupnijih mjerila, i to onih područja koja se smatraju važnima (npr. planovi većih gradova) ili dijelova koji pripadaju području na glavnoj karti, ali su od njega prostorno udaljeni.

\section{Atlasi svijeta drugih nakladnika}

\subsection{Veliki atlas svijeta (VAS74)}

U izdanju Prosvete (Beograd) i Mladinske knjige (Ljubljana) te pod vodstvom priređivača hrvatskosrpskog izdanja Alfonsa Cvitanovića objavljen je 1974. VAS74 (399 str.). Prijevodni je atlas jer su karte (preuzete od Geographical Projects, Aldus Book i Kartographisches Institut Bertelsmann), tekstualno poglavlje (izvorno na slovenskom) i popisni dio prevedeni na hrvatski jezik. Tematske karte Jugoslavije dodane su u slovenskom izdanju; ovdje su prilagođene. Poglavlje o pisanju i čitanju geografskih imena, koje je napisao Alfonso Cvitanović, čini posebnu vrijednost atlasa. Najopsežniji je prilog o pisanju i čitanju geografskih imena s jasnim načelima pisanja dotad (uz primjere). Podrobno su po državama ispisani izgovori i naglasci pojedinih slova u najraširenijim jezicima. Specifičnosti su Atlasa i podloge geografskih karata izrađene snimanjem posebno osvjetljenih reljefnih modela, kao i podjela tekstualnoga dijela po većim regijama, a ne državama.

Dvije su osnovne vrste geografskih karata, ovisno o uporabi boja: a) višebojne s naglaskom na: reljef, klimatsko-vegetacijske pojaseve, političku podjelu, b) dvobojne sa zelenom bojom kopnenih dijelova i svjetloplavom morskih dijelova. Višebojne karte prikazuju svijet, kontinente i veće kontinentske cjeline pa su to karte sitnijih mjerila - od 1:30 000000 (svijet) do 1:2 765000 (Jugoslavija). Dvobojne karte prikazuju manja područja, najčešće regije, pa su krupnijih mjerila - do 1:1622 400 (istočni i zapadni dio Jugoslavije).

Atlas se sastoji od triju dijelova: tekstualnoga, kartografskoga i popisnoga. Struktura:

- $\quad$ Svemir (4)

- $\quad$ Svijet (5)

Geografska i klimatska karta svijeta. 
- Geografske i tematske karte (169)

Karte svijeta, kontinenata i oceana te država, dijelova ili skupina država i Jugoslavije raspoređenih po kontinentima i oceanima. Tematske karte uz kontinente uglavnom prikazuju prirodne elemente prostora. Političke i povijesne karate na početku atlasa tematikom bi pripadale bloku s tematskim kartama koje predočuju društvene elemente prostora (naseljenost, religije, trgovina, promet, stanovništvo, gospodarstvo i dr.), a nalaze se na kraju.

- Svijet u riječi i slici (109)

Opis velikih regija (npr. Južna Europa, Jugoistočna Azija, Sjeverna Afrika, Američka prevlaka) te sažeti pregled država i ovisnih područja po redoslijedu kontinenata: Europa, Azija, Afrika, Amerika, Australija, Antarktika (smještaj i položaj, reljef, klima i bilini svijet, gospodarstvo, stanovništvo i naseljenost).

- Važnija geografska otkrića (2)

Kronološki popis najvažnijih geografskih otkrića od 2500. pr. Kr. do 1969.

- Zemljopisni nazivi (7)

Rječnik naziva geografskih objekata iz stranih jezika.

- Popis zemljopisnih imena (79)

- Pisanje i čitanje geografskih imena (8)

\subsection{Atlas svijeta: novi pogled na Zemlju (AS80)}

Sveučilišna naklada Liber objavila je 1978. prvo, a 1980. drugo izdanje AS80 (265 str.), koje se ovdje analizira. Prijevodni je atlas njemačkog izvornika (Bertelsmann), a glavni urednik hrvatskoga izdanja bio je Milan Mirić (urednik Radovan Radovinović). Urednici ističu kako je svrha atlasa (5) »da pred našu kulturnu javnost izađemo s prvim jugoslavenskim izdanjem Neuer Grosser Weltatlasa«, te kako on »predstavlja kompletno geografsko štivo i specijalnu enciklopediju Zemlje u samo jednom tomu«. Novina je u tome »što su autori ovog geografskog atlasa usporedili i sučelili konvencionalnu geografsku kartu sa snimkom iz svemira«. (Sadržava 67 satelitskih snimaka i 68 fotografija.) Navodeći podatak o milijunskoj nakladi izvornika u nekim europskim državama, urednici ističu da je »jedan od najuspješnijih u svijetu u posljednjih desetak godina $\ll$. 
U izradi su sudjelovali Ivan Bertić i Veljko Rogić, koji su atlas dopunili tekstom i kartama o Jugoslaviji. Neke tablične preglede izradili su suradnici hrvatskoga nakladnika, a karta Jugoslavije proizišla je iz radionice beogradske Geokarte. Mjerila geografskih karata kontinenata, regija i država variraju od 1:500 000 (Ruhr) do 1:60 000000 (svijet). Karta Jugoslavije podijeljena na dijelove u mjerilu je 1:1000 000 .

Atlas se sastoji od četiriju dijelova: uvodnoga, kartografsko-tekstualnoga, statističkoga i popisnoga. Struktura:

- Nova slika svijeta (20)

Pregled tehnika snimanja iz zraka. Opis svemira, Sunčeva sustava, Zemlje u svemiru, Zemljinih sila, procesa u atmosferi i klimatskih obilježja, stanovništva i svjetske prehrane te potrošnje energije. Tematske karte svijeta su na dvije stranice (reljefna, klimatska i politička) ili na pola stranice. (raspodjela nekih demografskih i gospodarskih pokazatelja).

- Europa*(82)

- Azija* $^{(20)}$

- $\quad$ Afrika* (8)

- Australija i Oceanija* (6)

- Sjeverna Amerika sa Srednjom Amerikom*(14)

- Južna Amerika* (6)

- Arktik i Antarktika*(3)

- Rječnik izvornih geografskih pojmova (3)

- Statistički prilog (30)

Tablični prikaz podataka o površini, stanovništvu, naseljenosti, glavnim i najvećim gradovima po državama i kontinentima.

- Kazalo toponima (60)

Sadržava više od 50000 toponima.

Pregled kontinenata i država po abecednom redu (*) obuhvaća oko 140 karata i skica: reljefne, političke, klimatske karte i ponegdje druge tematske karte/skice kontinenta (npr. međunarodni savezi u Europi, narodi i jezici Azije, dekolonizacija u Africi), dijelova kontinenata i država. Sadržaji se tekstualno obrađuju po regijama (npr. Sjeverna Europa, Indijski potkontinent), državama i dijelovima država (npr. Ruhr, Američki jug). 


\subsection{Zemljopisni atlas: svijet u brojkama, zemlja i svemir, države svijeta (ZA85)}

U izdanju Mladinske knjige 1985. objavljen je ZA85 (310 str.), koji je za hrvatsko izdanje priredio Alfonso Cvitanović. Karte (ukupno 260 i 46 planova gradova) preuzete su i prevedene od njemačkog Diercke Weltatlasa, a tekstualni dio od slovenskoga Atlasa sveta za osnovne in srednje šle (B. Ingolič i J. Medved, 1979 i B. Ingolič, 1983). U Atlasu je 60 satelitskih snimaka. Premda je usredotočen na školsku populaciju, u analizu je uvršten zbog svoje opsežnosti i informativnosti pa može poslužiti i širem krugu korisnika. Geografske karte su u mjerilima od 1:500 000 (npr. Beč s okolicom) do 1: 180000000 (svijet); mnogo je topografskih karata krupnijih mjerila (npr. Amsterdam s okolicom $1: 250$ 000) i planova gradova (npr. Istanbul, Washington, London na 1: 50 000).

Atlas se sastoji od triju dijelova: tekstualnoga, kartografskoga i popisnoga. Struktura:

- $\quad$ Svijet u brojkama (9)

Tablični prikaz proizvodnje poljoprivrednih proizvoda, stoke, mesa, ruda i prometa u državama po rangu.

- Pisanje i čitanje zemljopisnih imena (1)

O pisanju geografskih imena i izgovoru stranih geografskih imena iz odabranih jezika po državama.

- O nastanku karata (5)

Prikaz vrsta snimaka i karata (planovi, topografske karte, tematske karte i dr.).

- Jugoslavija (10)

Topografska karta Jugoslavije i dijelova s nekoliko tematskih karata po stranici.

- Europa* $(62)$

- Azija* (27)

- Afrika* (9)

- Amerika*(23)

- Australija i Oceanija* (4)

- Polarni krajevi*(2)

- $\quad$ Svijet (23)

Tematske karte i dijagrami koji prikazuju distribuciju izdvojenih obilježja prostora. 
- Zemlja i svemir (60)

Tematski strukturiran tekstualni pregled istraživanja svemira, Sunčeva sustava i građe Zemlje te obilježja atmosfere, klime, mora, vulkana, oblikovanja reljefa, unutrašnjih voda, ledenjaka, pustinja, morskih obala i dr.

- Države svijeta (14)

Statistički pregled osnovnih podataka o državama.

- Neki osnovni pojmovi (3)

- Popis zemljopisnih imena (60)

Sadržava 19000 toponima.

Kartografski prikaz država i skupina država po kontinentima (*) obuhvaća geografske karte, mnoge tematske karte i planove gradova, skice, topografske karte krupnijih mjerila, dijagrame i satelitske snimke.

\subsection{Enciklopedijski atlas svijeta (EAS97)}

Nakladnička kuća Extrade tiskala je 1997. EAS97 (512 str.). Prijevod je drugoga proširenog izdanja britanskog The encyclopedia of world geography (gl. ur. Graham Bateman) iz 1996. Stručnu redakturu hrvatskoga izdanja obavio je Hrvoje Turk. Premda je po mnogočemu različit u odnosu na ostale atlase, ovdje je uvršten jer je pristupom najsličniji zavodskim izdanjima. Kao enciklopedijski priručnik, sljedećih je obilježja: prevladava tekstualni enciklopedijsko-geografski pregled država, što znači da nema kartografskoga bloka ni tematskih karata; općenito je malo karata i grafičkih priloga, ali je dosta fotografija; nema dijela s obradom svijeta; države su grupirane po regijama. Cilj atlasa je (6): »omogućiti, na jednom mjestu, sveobuhvatan prikaz svih zemalja svijeta...Čitalac na kraju dobiva bolji pregled svijeta, bolji no što mu to omogućuje bilo koji atlas i sadrži više informacija o svakoj zemlji od bilo koje opće enciklopedije«.

Malobrojne karte ponajprije su ilustrativna dopuna tekstu, a ne ozbiljni kartografski prikazi. Višebojne su, ali nemaju ni mjerilo ni kartografsku mrežu. Na početku većih poglavlja regije su prikazane reljefnom kartom bez okolnoga prostora s malom položajnom skicom. Karte država jednostavni su prikazi osnovnih elemenata prostora (obala, granice, najveća naselja, jezera i rijeke). Svijet je predočen dvjema kartama, reljefnom i političkom, također bez matematičkih elemenata. Sadržavaju vrlo malo toponima, uglavnom hrvatskih egzonima (prilagođenica) najistaknutijih geografskih objekata. 
Atlas se sastoji od dvaju dijelova: tekstualnoga i popisnoga. Struktura:

- $\quad$ Pregled regija i država (486)

Pregled država po regijama (npr. Središnja Afrika, Nordijske zemlje, zemlje Beneluksa, Jugozapadna Azija) prema sljedećem redoslijedu kontinenata: Sjeverna Amerika, Srednja Amerika, Južna Amerika, Afrika, Europa, Azija, Australija, Antarktika. Sažetije se obrađuju i ovisna područja. Na početku svake regije (ukupno 22) geografska je karta područja. Osnovnu strukturu obrade države čine tri poglavlja (geografija, društvo, gospodarstvo) s podatcima o reljefu, klimi, vodama, vegetaciji, biljnom i životinjskom svijetu, sažetim povijesnim podatcima, društvenom uređenju, kulturnim obilježjima stanovništva i gospodarskim djelatnostima (rudni resursi, glavne gospodarske grane, prometnice, zdravstvo, školstvo). Države se predstavljaju tekstom, jednostavnom geografskom i položajnom kartom te zastavom i fotografijama s kraćim opisima. Opći podatci izdvojeni su u tekstualnom okviru.

- Rječnik odabranih pojmova (5)

- $\quad$ Kazalo toponima (8)

\subsection{Atlas svijeta 2000: novi pogled na Zemlju (AS2000/98)}

Mozaik knjiga objavila je 1998. Atlas svijeta 2000 na 376 stranice. Prijevod je njemačkog Die Welt, Atlas International Bertelsmann, koji je za hrvatsko izdanje uredila Ivanka Borovac. Dodatak u hrvatskom izdanju su karte Srednje Europe na kojima je i Hrvatska. Nema tekstualnoga dijela ni tematskih karata. Geografske karte izrađene su u digitalnoj tehnici, što je unijelo novine u predočivanju reljefa. Posebnosti atlasa su: jedinstvena mjerila $u$ najvećem broju karata, uporaba boja u predočivanju ekopojaseva, ${ }^{9}$ a ne reljefa (koji se predočuje sjenčanjem), detaljna cestovna i željeznička mreža s klasificiranim prometnicama te satelitske snimke. Ističe se (V) kako atlas »postavlja nova mjerila u grafičkome oblikovanju, množini informacija i praktičnoj uporabnoj vrijednosti«. Želja mu je razvijati ekološku svijest i promovirati načela jednakosti. Atlas ima vrlo malo teksta, ali zato pruža mnogo informacija na kartama; bogatiji je topografskim znakovima od drugih atlasa.

9 Primjerice, nizine nisu obojane uobičajenom zelenom bojom, a gorja smeđom, nego se tonovi zelene boje pojavljuju u svim ekopojasevima u kojima prevladava šumska vegetacija. Nijanse smeđe boje češće su u pustinjskim i polupustinjskim područjima; siva prevladava u borealnoj zoni, subpolarnom i polarnom pojasu. 
Sve su geografske karte izrađene u trima mjerilima, osim karata svijeta polarnih područja (1:27 000 000) i Tihog oceana (1:50 000 000) te nekih manjih otoka. Karte kontinenata i ostalih oceana su u mjerilu 1:40 000 000. Najveći broj karata je u mjerilu 1: 4500000 (dijelovi kontinenata, države i dijelovi država). Karte Srednje Europe u mjerilu 1:900 000 svojim se sadržajem i preciznosti prikaza gotovo približavaju topografskim kartama i autokartama.

Atlas se sastoji od dvaju dijelova: kartografskoga i popisnoga. Struktura:

- Pregled i vrste zemljovida (4)

- Tumač znakova na zemljovidima (4)

Detaljna objašnjenja o prikazivanju reljefa, dubina, kopnenih voda, leda, ekoloških zona, političkih i drugih granica, naselja, prometnica, znamenitosti, imena naselja te prometnica i topografskih znakova na kartama 1:900 000 .

- $\quad$ Satelitske snimke (9)

- Svijet*(16)

- Europa* $^{*}(23)$

- Azija*(63)

- Australija i Oceanija* (15)

- Afrika*(39)

- Sjeverna i Srednja Amerika*(39)

- Južna Amerika* (23)

- Srednja Europa* (23)

- Rječnik zemljopisnih pojmova (2)

- Kazalo država i područja (2)

- Kazalo zemljopisnih pojmova (121)

Uz toponim je simbol za tip imenovanoga geografskoga objekta, državu i upravnu jedinicu u kojoj se objekt nalazi.

Kartografski prikaz svijeta, kontinenata, oceana i polarnih predjela te država i skupina država po kontinentima $\left(^{*}\right)$. Na početku svakoga kontinenta je satelitski snimak. 


\subsection{Veliki atlas svijeta (VAS02)}

Godine 2002. u izdanju Leo-commerca objavljen je hrvatski prijevod britanskog $D K$ Reference Atlas Of The World (2001; autor Andrew Heritage), VAS02 (354 str.), koji je uredio Leonardo Marušić, a stručnu redakturu prevedenoga teksta i geografskih imena napravili su Ivan Bertić i Zlatko Pepeonik. Navodi se (V) kako je riječ o »referencijalnom izdanju s odlikama vrlo razgranate informatičnosti enciklopedijskih obilježja«. Iznimno je bogat ilustracijama. Raspon mjerila geografskih karata kontinenata, regija i država je širok (npr. Nauru je prikazan na 1: 500 000, a svijet na 1: 60000 000).

Atlas se sastoji od četiriju dijelova: uvodnoga, kartografsko-tekstualnoga, statističkoga i popisnoga. Struktura:

- $\quad$ Svijet (23)

Opis Sunčeva sustava i Zemlje (reljef, građa, krajolik, oceani, mora, klima, bilini i životinjski svijet, stanovništvo, naselja, gospodarstvo, države i dr.) s mnogim tematskim kartama.

- Hrvatska (8)

Topografska karta i nekoliko tematskih karata (s podacima za stanovništvo), sažeti podatci o Hrvatskoj (povijesni razvoj, priroda, teritorijalna podjela, stanovništvo, gospodarstvo) te podjela na geografske regije.

- Atlas svijeta (208)

Pregled kontinenata unutar kojih su obrađene regije, države i ovisna područja prema redoslijedu: Sjeverna i Srednja Amerika, Južna Amerika, Afrika, Europa, Azija, Australija i Oceanija, Antarktika. Sadržava poglavlja o reljefu i klimi, državama i stanovništvu te gospodarstvu (s mnogim tematskim kartama). Podatci se iznose tematski (korištenje zemljišta, neka obilježja krajolika, promet i industrija). Sadržava više od 450 karata i oko 800 fotografija.

- Geografske usporedbe i vremenske zone (3)

Statistički prikaz geografskih ekstrema i tematska karta vremenskih zona.

- Države svijeta (7)

Statistički pregled osnovnih podataka o državama.

- Rječnik geografskih pojmova i kazalo toponima iz Hrvatske (2)

- Kazalo toponima (133)

Sadržava 60000 toponima. 


\subsection{Atlas svijeta za 21. stoljeće (AS21./03)}

Godine 2003. Naklada Fran objavila je prijevodni AS21./03 na 751 stranici, koji je s izvorno američkoga izdanja The 21st Century World Atlas za hrvatske korisnike uredio Miljenko Lapaine sa suradnicima (Stanislav Frangeš preveo je toponime, a u obradi geoloških i batimetrijskih sadržaja sudjelovali su Ivan Gušić i Vladimir Tomić). Posebnost je što sadržava oko 300 satelitskih snimaka i referentnih karata na kojima boje predočuju vegetaciju, oko 200 digitalnih modela reljefa na crnim podlogama, oko 400 tematskih karata s prirodnim i društvenim elementima prostora, oko 500 tematskih karata država i oko 1700 grafikona. Donose se osnovni podatci o državama. Geografske karte su u mjerilima od 1:200 000000 i 1 : 70000000 (svijet), do krupnih mjerila za prikaze manjih područja (npr. otoka). Teško je odraditi krupnija mjerila jer nisu naznačena u svojem brojčanom obliku nego samo u linearnom. ${ }^{10}$

Atlas se sastoji od četiriju dijelova: uvodnoga, kartografskoga (tematske karte), tekstualno-kartografskoga i popisnoga. Struktura:

- Geopolitički okvir* (31)

Satelitske snimke, digitalni model reljefa, batimetrija svijeta i dijelova svijeta.

- Klimatologija, geologija i biogeografija* (31)

- Demografija i socijalni pokazatelji* (42)

- Osnovne ekonomske djelatnosti* (44)

- Industrija, trgovina i promet* (65)

- $\quad$ Afrika** (94)

- $\quad$ Amerika** (104)

- $\quad$ Azija**(98)

- $\quad$ Europa** $^{*}(88)$

- Oceanija** (38)

- $\quad$ Rječnik (1)

Popis odabranih geografskih naziva s prijevodom.

- Kazalo geografskih imena (78)

Sadržava oko 60000 toponima. Uz toponim je kratica države u kojoj se geografski objekt nalazi i njegove geografske koordinate.

10 Za karte većih područja navode se mjerila 1:100 000000 za sve kontinente, osim za Europu, SAD i Japan koji su prikazani u mjerilu 1:5000 000. 
Poglavlja u kartografskom dijelu (*) sadržavaju tematske karte svijeta prema navedenim pokazateljima (npr. reljefna, politička, geopolitička, jezična i religijska karta svijeta; klimatske zone, gustoća stanovništva, BDP po stanovniku; poljoprivredno zemlijšte, raširenost različitih usjeva; rudno bogatstvo, izvori energije, turistički pokazatelji, promet i dr.). Pregled država po kontinentima raspoređenima po abecednom redoslijedu u izvorniku $(* *)$ sadržava nekoliko satelitskih snimaka kontinenta i dijelova, digitalne modele reljefa, kartu podmorja (Faričić 2004), reljefnu i političku kartu kontinenta, nekoliko geografskih karata regija i tekstualno-kartografski pregled država (s glavnim tekstom, osnovnim podatcima u posebnom okviru, zastavom, geografskom kartom s izdvojenom državom te grafikonima i tematskim kartama).

\subsection{Veliki obiteljski atlas svijeta (VOAS04)}

Naklada Ljevak i Monde Neuf, pod uredničkom palicom Ivana Bertića i Denisa Šehića, objavili su 2004., na 337 stranice, VOAS04. Sastoji se od preuzetih karata svijeta nakladnika Monde Neuf i opširnoga dodatka o Hrvatskoj koji su izrađivali domaći autori pa je tek djelomično prijevodni. Stručni recenzenti su Franc Lovrenčak (za svijet) i Zoran Curić (za Hrvatsku), a autori karata, tekstova i statističkoga priloga Denis i Demir Šehić te Ivan Bertić. Želja je autora bila da u jednom djelu pruže (3) »na pristupačan način informacije i osnovna znanja o Zemlji te državama i stanovnicima svijeta«. Geografske karte su u mjerilima od 1:63 700000 (svijet) do 1:500 000 (dijelovi Hrvatske), a tematske od 1:69500 000 (svijet) do 1:1 750000 (Hrvatska).

Atlas se sastoji od četiriju dijelova: uvodnoga, kartografsko-tekstualnoga, statističkoga i popisnoga. Struktura:

- Sunčev sustav (2)

- $\quad$ Svijet (45)

Dvostranične tematske karte (23) s tablicama i kratkim popratnim tekstom koje prikazuju: opća i politička obilježja prostora, geološku prošlost, reljef, vode, temperature zraka, godišnje količine padalina, klimatske tipove, morske struje, tla, vegetaciju, stanovništvo, rase, religije, jezike, poljoprivredu, ribarstvo i šumarstvo, rudarstvo, energetiku i industriju, promet, bruto društveni proizvod i dr.

- Europa* $^{*}(28)$

- Azija* (22)

- Afrika* (20) 
- Sjeverna Amerika* (24)

- Južna Amerika*(20)

- Australija i Oceanija* (16)

- Polarni krajevi* (4)

- Hrvatska (54)

Topografske i geografske karte Hrvatske i regija (Slavonija i Baranja; Središnja Hrvatska; Istra, Kvarner, Gorski kotar i Lika; Sjeverna Dalmacija; Južna Dalmacija). Slijedi 30 tematskih karata s tekstom i grafičkim prilozima koje prikazuju: reljef, geologiju, seizmiku, kopnene vode, temperature zraka, padaline, klimatske regije, tla, zaštićena područja, stanovništvo, narodnosni sastav, nacionalne manjine, poljoprivredu, šumarstvo, rudarstvo, energetiku, industriju, promet, turizam, regije, županije i dr.

- Statistički prilog (23)

Tablice s ekstremima i proizvodnjom odabranih proizvoda po državama. Pregled država (oblik vladavine, glavni grad, površina, stanovništvo, gradsko stanovništvo, BDP, vanjska trgovina, turistički devizni priljev). Hrvatski je dio odvojen (tablice s ekstremima, podatcima o stanovništvu, županijama i naseljima).

- Kazalo geografskih imena (65)

Kartografski prikaz država i regija po kontinentima $(*)$ obuhvaća geografsku kartu, i tematske karte: političku, gospodarsku, karte temperature zraka, padalina i prirodnih vegetacijskih područja, promjene broja stanovnika i gustoće naseljenosti, BDP-a i međunarodnih integracija. Slijede karte regija (npr. Srednja Europa, Jugoistočna Europa, Jugozapadna Azija, Bliski istok, Sjeverna Afrika, Srednja Amerika) i država te Arktika i Antarktike. Uz svaku je kartu kraći tekst s glavnim prirodnim i društvenim obilježjima te tablični opći podatci o državi.

\subsection{Atlantika: veliki satelitski atlas svijeta (ATL07)}

Godine 2007. u izdanju Mozaik knjige, pod uredništvom Vida Jakše Opačića, na 502 stranice, objavljen je ATL07. Prijevodni je atlas njemačkog Attantica - Der neue grosse Satelliten-Weltatlas. Posebnost je više od 100 satelitskih snimaka prirodnih i kulturnih pejzaža (npr. velikih gradova). Okvirima na geografskim kartama označena su područja koje te snimke pokrivaju. Sadržava mnogo fotografija. Nema uvodnoga dijela o geografskim obilježjima kontinenata ili država. Geografske karte i satelitske 
snimke su u mjerilima 1: 85000000 (svijet), 1:30 000000 (kontinenti) i 1:36 500000 (polarni krajevi), dok su geografske karte dijelova kontinenata jedinstveni te uglavnom u mjerilima 1:3000 000 (dijelovi Europe) i 1: 4500000 (dijelovi ostalih kontinenata).

Atlas se sastoji od triju dijelova: kartografskoga, kartografsko-tekstualnoga i popisnoga. Struktura:

- $\quad$ Satelitske snimke (3)

O satelitskim snimkama, njihovoj razlučivosti, bojama, digitalnim podatcima o reljefu.

- $\quad$ Svijet (38)

Geografske karte i satelitske snimke svijeta i kontinenata u jedinstvenim mjerilima.

- Europa*(66)

- Afrika*(67)

- Sjeverna i Srednja Amerika* (63)

- Južna Amerika* (47)

- $\quad$ Azija* (87)

- Australija i Oceanija* (31)

- Kazalo geografskih imena (93)

Uz toponim je simbol za tip imenovanoga geografskog objekta i državu u kojoj se objekt nalazi.

Kartografsko-tekstualni pregled $(*)$ sadržava geografske karte kontinenata i njihovih dijelova te satelitske snimke odabranih manjih područja i tekstove vezane uz njih. Informacije su predstavljene isključivo tematski (o pojedinim područjima), a odabrani su dijelovi koje se smatra osobito zanimljivima (npr. pod naslovom Prag satelitska je snimka središta Praga, isječak karte s okvirom koji je prikazan na snimci, kratak uvodni tekst s najvažnijim podatcima o gradu i osam kratkih tekstova o njegovim znamenitostima; na sličan su način obrađene sve ostale teme: Everglades, Osaka, Uluru, Veliki koralini greben, Namib, Labrador i dr.).

\subsection{Atlas svijeta (AS08)}

Godine 2008. u izdanju Mozaik knjige i pod uredništvom Vida Jakše Opačića objavljen je AS08 na 400 stranica. Prijevod je atlasa The Reader's Digest World atlas i u 
potpunosti slijedi koncepciju izvornika, dakle nije dopunjen sadržajima o Hrvatskoj. Karte su prikupljene iz međunarodnih izdanja američkoga nakladnika i prevedene. Ideja je da u radionici Reader's Digesta - poznatog nakladnika atlasnih izdanja - nastane suvremeni prikaz svijeta na njima svojstven način: u tekstualnom dijelu tematski, u kartografskom regionalni. Karte su u mjerilima od 1:60 000000 (svijet) do krupnijih mjerila za prikaze manjih područja (npr. otoka Naurua 1 : 250 000). Malobrojne tematske karte kontinenata imaju obilježja skica.

Atlas se sastoji od triju dijelova: tekstualno-ilustrativnoga, kartografskoga i popisnoga. Struktura:

- Geografska karta svijeta (2)

- Politička karta svijeta (2)

- Tematska poglavlja (50)

Bogato ilustrirana tekstualna poglavlja s podatcima o svemiru, građi Zemlje i reljefu, kopnu, oceanima, vremenu i živom svijetu na Zemlji po izdvojenim temama. Slijede poglavlja o kontinentima (redoslijed: Sjeverna Amerika, Južna Amerika, Europa, Afrika, Azija, Australija i Oceanija) s izdvojenim temama. Na kraju su tematska poglavlja s tematskim kartama/skicama i statističkim podatcima na svjetskoj razini (npr. naseljenost, gradovi, izvori energije, stanovništvo, životni standard, društvo, ekstremi).

- $\quad$ Australija i Oceanija* (20)

- $\quad$ Azija* (52)

- $\quad$ Europa* (72)

- $\quad$ Afrika* (24)

- Sjeverna i Srednja Amerika* (12)

- Južna Amerika* (20)

- Polovi i oceani* (5)

- Kazalo (96)

Sadržava oko 90000 toponima. Uz toponim je simbol za tip imenovanoga geografskoga objekta. Sadržava i osnovne statističke podatke o državama u posebnim okvirima.

Pregled kontinenta $\left(^{*}\right)$ započinje njegovom skicom s najvažnijim statističkim podatcima te ekstremima. Slijedi shematizirana karta s izdvojenim podatcima, tematskim kartama, tablicama i kraćim tekstovima te manjim satelitskim snimkama. 
Nakon političke karte su regionalne geografske karte. Pojedini predjeli prikazani su iz ptičje perspektive na presavijenim stranicama, a reljef na njima prikazan je tehnikama kojima se dobiva dojam plastičnosti reljefa (npr. Himalaja, Afrički tektonski jarak, Sredozemlje).

\section{Sinteza istraživanja}

\subsection{Sličnosti analiziranih atlasa}

Uočeno je nekoliko zajedničkih karakteristika svih ili većine atlasa.

a) Slijeđenje enciklopedičkih principa. Gotovo sve atlase karakteriziraju principi koji su, prema Jeciću (2013), svojstveni enciklopedijskim djelima, a očituju se u različitim obilježjima (atlasa). Budući da im je obuhvat prostorne stvarnosti svijet, predmetom obrade atlasi svijeta inherentno su sveobuhvatni. U svim se atlasima uporabom različitih kartografskih projekcija i mjerila na geografskim kartama prikazuju cijeli svijet, kontinenti i oceani, skupine država (regije), države, dijelovi država, ponegdje i planovi većih gradova. Međutim, atlasi koji tematski, a ne jedinično, obrađuju države ili regije (npr. ATL07, AS08) u predstavljanju prostornih jedinica nisu obuhvatni, a time ni konsolidirani (dosljedni).

U obradi sadržaja svi su (ili barem nastoje biti) maksimalno točni, organizirani (tj. slijede zadanu strukturu), ažurni, tj. aktualni (donose najnovije brojčane i druge informacije; u svakom sljedećem zavodskom atlasu podatci o državama osvježeni su i dopunjeni najnovijim podatcima popisne statistike), a neki su, osobito zavodski atlasi, sažetiji od drugih. U odabiru sadržaja vjerodostojni su (rabe provjerene podatke) i relevantni (premda je odabir bitnih podataka podložan subjektivnoj prosudbi autora, uglavnom se svugdje navode iste, najvažnije vrste podataka).

b) Pristup u obradi tekstualnih sadržaja. Očituje se u načinu predstavljanja geografskih sadržaja i dodijeljenom prostoru za tekstualnu obradu iskazanom brojem stranica ili redaka. Geografski atlasi u svojoj biti nisu značajnije podložni subjektivnim i ideološkim interpretacijama jer objekt njihova interesa i prikaza nije pojedinac, društvena skupina, društvo ili kultura, nego zadan, mjerljiv fizički prostor i najčešće vidljivi, u znatnoj mjeri mjerljivi odrazi ljudskog djelovanja u prostoru. Podatci o prostoru najčešće se dobivaju kvantitativnim metodama - promatranjem, mjerenjima i statističkom metodom - što u praksi znači da se, potkrjepljujući činjenice i tumačenja egzaktnim, brojčanim pokazateljima, u predstavljanju geografskih sadržaja teži maksimalnoj objektivnosti. Obilato se pritom služe tabličnim i grafičkim prikazima statističkih podataka prikupljenih za sve jedinice obrade, što ih čini usporedivima. 
Zavodski atlasi dobar su primjer težnje k objektivnosti, što je osobito izraženo pri obradi prirodnih obilježja prostora. Međutim, i u obradi društvenih obilježja kroz koju bi se zasigurno lakše moglo provući ideološko motrište autora/urednika - u člancima o državama uglavnom se nastojalo držati podalje od svake ideologije te prostor i društvene čimbenike koji utječu na nj prikazivati maksimalno objektivno. $\mathrm{U}$ svih sedam atlasa iznimku čini samo ${ }^{6} \mathrm{AS}$ u dijelu obrade društveno-političkoga uređenja i društveno-ekonomskoga razvoja Jugoslavije. U tim je dijelovima (koje nisu pisali geografi) nemoguće ne uočiti prenaglašenost u broju dodijeljenih stranica (čak 13) te uobičajene ideološke sadržaje i diskurs socijalističke Jugoslavije. Bez obzira na to, Feletar $(1989,251)$ hvali ukupnu duljinu poglavlja o Jugoslaviji u ${ }^{6} \mathrm{AS}$ (91 str.) jer »inače oskudijevamo u jugoslavenskim sintezama«. Iz današnje perspektive, prevladavajući činjenično utemeljen statistički pristup u predstavljanju sadržaja - s često zamornim nabrajanjem ili nizanjem tablica, bez ili sa zanemarivim udjelom interpretacija - u turbulentnom se društveno-političkom razdoblju druge polovice XX. st. dijelom pokazao razumnim izborom.

c) Pristup u koncepciji. Očituje se u rasporedu sadržaja, broju karata i ukupnom dodijeljenom prostoru (broju stranica) za obradu jedinice. U koncepciji je objektivnost najčešće zaobiđena. Većina atlasa prikazuje svijet iz perspektive zemlje iz koje potječe, odnosno iz zemlje izvornika, dajući svojoj državi, široj regiji i svojem kontinentu više prostora i veći broj karata krupnijega mjerila, smještajući ih na početak atlasa. Geografskim i interesnim udaljavanjem od države izvornika, broj karata i duljina tekstualnoga dijela uglavnom opadaju. Najbolji je primjer obrada država i regija iz Afrike, Australije i Oceanije te polarnih krajeva - područja koja su u svim atlasima obrađena s najmanjim brojem stranica i karata, najčešće na kraju atlasa. ${ }^{11}$

Na tu neobjektivnost upućuju urednici u AS2000/98 (V), želeći naglasiti prednosti svojega atlasa s kartama istih mjerila za sve dijelove svijeta (čime je cijeli svijet predstavljen na jednak način): »Kad bi atlas bio objavljen u Europi, svaka bi europska zemlja, makar i prosječne veličine, bila velika koliko Kina ili Indija, a ostali bi kontinenti bili obično nepravedno zapostavljeni... Jednostavno, poput naših djedova i baka, i mi smo skloni eurocentrizmu. Vidjeti sebe u središtu zbivanja nije samo pogrešaka u razmišljanju tipična za Europljane. Kinezi su, na primjer, svoju zemlju

11 Na primjer, u VAS74 Europa je prikazana s najviše karata na 37 stranica; područja iz Zapadne Europe su na sedam karata u mjerilu 1:2-3 000 000, dok su Istočna i Jugoistočna Europa (bez 10 karata Jugoslavije) na tri karte u sitnijima mjerilima; Azija i Afrika su na 20 stranica, a Australija s Oceanijom na pet stranica. U VAS02 najviše stranica zauzima SAD (čak 24); Afrika je na 17 stranica, dok su Njemačka, Francuska i UK na dvije stranice. U ZA85 Europi su posvećene 62 stranice (i 10 Jugoslaviji); SSSR-u i SAD-u 10 stranica, a Africi devet. U EAS97 najopširnije su obrađene Europa (142 str.), Azija (122 str.) i Amerike (106 str.); Afrika, Australija, Oceanija i Antarktika zajedno su na oko 100 stranica; 50 stranica dodijeljeno je SAD-u, dok su UK, Kanada i Francuska na 10 stranica; mnoge su otočne države u Oceaniji na pola stranice. 
nazvali 'Carstvom središta'.«Ipak, i u tom atlasu najprije je obrađena Europa, potom Azija, a na kraju Južna Amerika, pa raspored karata upućuje na vlastitu optiku. ${ }^{12}$

Objektivnost je djelomično ostvarena u ATL07, gdje su svi dijelovi Europe prikazani u mjerilu 1:3000 000. Tako je Njemačka na zajedničkoj karti Srednje Europe, Španjolska na karti Pirinejskoga poluotoka, a Hrvatska na karti širega srednjoeuropskoga područja. I drugi dijelovi svijeta ravnopravno su prikazani u mjerilu $1: 4500$ 000. Objektivnost se u zavodskim atlasima očituje u prostoru dodijeljenom za prezentaciju stranih država, pri čemu se rukovodilo veličinom i značenjem države u svijetu, ali i dostupnim podatcima.

Kao posljedica pristranosti u koncepciji, Jugoistočna je Europa prostorom za obradu i brojem karata (uglavnom sitnijih mjerila) u prijevodnim atlasima prikazana skromno. Stoga su priređivači nekih hrvatskih izdanja dodavali sadržaje o Jugoslaviji/Hrvatskoj. U starijima dopunski dio je priličan (u VAS74 Jugoslavija je na 10 str., u AS80 na 18, a u ZA85 na 10), u novijima je Hrvatska obrađena tek na nekoliko stranica i karata (u VAS02 na 8 str.), a u nekima dopunskoga dijela nema (ATL07, AS08).

d) Uporaba izražajnih sredstava. U svim atlasima korištena su sva uobičajena sredstva prikazivanja informacija - karte, tekst, tablice i grafički prilozi (fotografije, crteži, grafikoni i dijagrami) - različite zastupljenosti. U nekima prevladavaju karte (npr. AS21./03, ATL07, AS08), u nekima tekst (npr. EAS97).

e) Način predočivanja reljefa i uporaba kartografskih znakova na geografskim kartama. Reljef se uglavnom predočuje bojama i sjenčanjem. Iznimke su AS80 (na karti Jugoslavije reljef je predočen izohipsama) i AS2000/98 (sjenčanjem je prikazan reljef, a bojama ekopojasevi). Uobičajenim se simbolima, objašnjenima u tumaču znakova, prikazuju prirodna i društvena obilježja prostora (granice, prometnice, vodene površine, pustinje, pojedinačni lokaliteti, poput naselja, kota, prijevoja, rudnika, arheoloških nalazišta i dr.), a hipsometrijskom ljestvicom boja reljef. Karte su višebojne (osim zavodskih »političkih« karata i dvobojnih u VAS74) te imaju kartografsku mrežu.

f) Obilježja tematskih karata. Tematske se karte nalaze u većini atlasa; prikazuju izdvojene prirodne i društvene elemente prostora pa mogu biti političke, klimatske, geološke, demografske, gospodarske, prometne, povijesne i dr. Višebojne su; uglavnom nemaju mjerilo i kartografsku mrežu; često su male pa podsjećaju na skice. Ovisno o sadržaju koji prikazuju, u podlozi imaju (ili nemaju) reljef.

12 Prema redoslijedu država iznimku čine dva atlasa. U AS21./03 kontinenti su obrađeni prema abecednom redu, pa je Afrika na prvom mjestu, a Oceanija na zadnjem. U AS08 prvo mjesto zauzima Australija i Oceanija, a potom se kontinenti redaju prema pružanju u smjeru zapada (Azija, Europa, Afrika, Amerike). 


\subsection{Posebnosti zavodskih atlasa}

Doprinos zavodskih atlasa očituje se u razlikama, odnosno njihovim posebnostima u odnosu na prijevodne atlase. Zavodski atlasi ističu se po tome što:

a) prikazuju svijet iz domaće perspektive, što se očituje u opširnijim tekstualnim poglavljima o Jugoslaviji/Hrvatskoj, u većem broju karata, i to krupnih mjerila, Jugoslavije/Hrvatske i okolnih područja (npr. Jugoistočna, Južna i Srednja Europa) u odnosu na ona udaljena te u rasporedu država (Europa se uvijek predstavlja prva). Tako je u ${ }^{1}$ AS 18 stranica teksta i 15 karata na 20 stranica posvećeno Jugoslaviji, a dok je Afrika na 10 karata i 12 stranica. U obradi država u ${ }^{1} \mathrm{AS}$ dodan je kratak dio o trgovini s Jugoslavijom. U ${ }^{6} \mathrm{AS}$ čak je 91 stranica o Jugoslaviji. Iznimka je samo ${ }^{7} \mathrm{AS}$, u kojem je Hrvatska obrađena na jednak način i brojem stranica koji odgovara sličnim državama.

b) odražavaju visoku stručnost u obradi sadržaja, primjenom dvaju načela:

1) obuhvatnost, tj. insistiranje na donošenju što više podataka, i to iz službenih i provjerenih izvora, osobito u tekstualnom dijelu (nacionalne statistike, godišnjaci i bilteni UN-a, godišnjaci stranih leksikografskih kuća)

2) dosljednost, i to u: koncepciji (struktura s trima jasno odvojenim cjelinama), odabiru sadržaja (obrađuju se isti sadržaji), strukturi sadržaja (ista je struktura jedinice obrade) te u predstavljanju podataka (predstavljene su iste vrste podataka).

c) sadržavaju pojačanu tekstualnu sastavnicu, u čemu se očituje zavodski enciklopedički pristup obradi geografskih jedinica. Značajan dio atlasa posvećen je enciklopedijski sastavljenom statističko-tekstualnom pregledu svijeta, kontinenata i država s tematskim kartama manjeg formata i fotografijama. Stoga je to priručnik u kojem se ne pruža samo informacija o lokaciji pojedinoga geografskoga objekta na karti, nego se može pronaći cjelovit statističko-faktografski pregled političke karte svijeta (Klemenčić 1993; Klemenčić 2013). Za razliku od drugih atlasa u kojima je težište stavljeno na kartografsku zbirku (koja je s više karata krupnijih mjerila nerijetko bolja od one u zavodskim atlasima), zavodski su atlasi prilično uravnotežen spoj enciklopedijskoga i kartografskoga djela.

d) postavljaju norme u pisanju i uporabi geografskih imena $i z$ stranih jezika, osobito hrvatskih egzonima. Urednici se opširnije nego u drugim atlasima osvrću na načela pisanja toponima iz stranih jezika, koja nastoje dosljedno primjenjivati. Ćirilična su slavenska imena transliterirana, dok su latinična ostavljena u izvornom liku. Arapska, kineska, japanska i druga nelatinična imena pisana su »latiničnom grafijom koja se nalazi na poštanskim žigovima« ( ${ }^{1} \mathrm{AS}$, VIII), odnosno onako kako ih do- 
tične države prenose u latinicu; za kinesko se pismo upotrebljava pinyin. Često se za određene tipove geografskih objekata rabe hrvatski egzonimi (Crljenko, Klemenčić 2011). ${ }^{13} \mathrm{U}^{1} \mathrm{AS}$ u novim neovisnim afričkim državama zadržana su stara imena jer su još uvijek bila prisutna u međunarodnoj korespondenciji i trgovini. Ta se praksa nastavila u kasnijim atlasima. U ${ }^{7} \mathrm{AS}$ unosila su se izvorna imena i, kada postoje, hrvatski egzonimi. U imenima gradova od ${ }^{1} \mathrm{AS}$ do ${ }^{3} \mathrm{AS}$ davala se prednost egzonimima. ${ }^{14} \mathrm{Od}{ }^{4} \mathrm{AS}$ prednost imaju izvorna imena (endonimi). ${ }^{15}$ Takva je praksa i u prijevodnim atlasima. ${ }^{16}$ Razrađenim sustavom pisanja i uporabe geografskih imena iz stranih jezika, premda nisu standardizirani pa je u njihovoj uporabi raširena nedosljednost i često neopravdana višeimenost (Crljenko 2019), zavodski atlasi nisu samo mjerodavni, vjerodostojni i pouzdani izvori svojevrsnih normiranih toponima, nego su i bogata riznica povijesnih i suvremenih hrvatskih egzonima. Stoga se njima služe prevoditelji i priređivači prijevodnih atlasa, nerijetko preuzimajući zavodska toponimska rješenja. U širem smislu, zavodski atlasi potiču uporabu hrvatskog jezika.

e) predočuju vlastite karte. ${ }^{17} \mathrm{U}^{1} \mathrm{AS}$ (VIII) ističe se da su karte »izrađene u Leksikografskom zavodu prema najnovijim kartama pojedinih država i sekcijama Geografskog Instituta Fugoslavenske Narodne Armije...Sve karte i planove konstruirali su, nacrtali i reproducirali naši stručnjaci, a odštampane su bojama i na papiru domaće proizvodnje«. U ${ }^{6} \mathrm{AS}$ (VII) stoji da su predlošci karata Jugoslavije bile topografske i geografske karte Vojnogeografskog instituta iz Beograda i Hidrografskog instituta Jugoslavenske ratne mornarice iz Splita.

13 U ${ }^{1}$ AS (VII): »svi nazivi kontinenata, oceana, velikih jezera, mora, velikih otoka i poznatijih gorja pisani su onako kako je u nas odavna uobičajeno, npr. Grenland (umjesto Grønland), Korzika (umjesto Corse), Rajna (umjesto Rhein, Rhin) itd. Na isti način pisani su i nazivi gradova koji su u nas već davno odomaćeni.« U ${ }^{6} \mathrm{AS}$ (VII): »budući da je ovaj Atlas svijeta namijenjen domaćim korisnicima, nužno je bilo donositi i domaće oblike nekih naziva«.

14 U ${ }^{1}$ AS (VII) ističe se da je »u zagradama ipak upisan i naziv kako ga piše narod kome grad pripada, npr. Beč (Wien), Carigrad (Istanbul), Varšava (Warszawa) itd.«.

$15 \mathrm{U}{ }^{4} \mathrm{AS}$ (7): »Nazivi gradova upisani su kako ih pišu narodi kojima oni pripadaju; u zagradama su ipak upisani i nazivi koji su u nas već odavno udomaćeni, npr. Wien (Beč), Istanbul (Carigrad), Roma (Rim), itd.«.

16 U atlasima VAS74, AS80, AS 2000/98, VAS02, ATL07 i AS08 - koji su svi tiskani nakon donošenja UNGEGN-ovih rezolucija o smanjenju uporabe egzonima na račun endonima (od 1972) (Resolutions on exonyms, 2020) - prednost se davala endonimima, a egzonime se upisivalo samo ako su to davno udomaćena imena, i to na kartama krupnijih mjerila. Iznimke su ZA85 i VOAS04 u kojima je primijećena značajna zastupljenost hrvatskih egzonima (oba su atlasa namijenjena i učenicima). Poseban je AS21./03. U tekstualnom dijelu toponimi su se prevodili, dok na kartama i u kazalu toponima nisu. Taj se očiti nedostatak pokušao ublažiti izdvajanjem nekih toponima i njihovih pripadnih hrvatskih inačica na vrhu stranica u dijelu obrade država, no zbog nedostatka prostora na taj se način »riješio« vrlo mali broj toponima.

17 Pravo na korištenje kartografskih podloga nakladnici prijevodnih atlasa dogovarali su s inozemnim izdavačima. Prijevode toponima i eventualne prateće sadržaje izrađivali su u suradnji s domaćim stručnjacima (Richter 1996; Klemenčić 2013). 
f) primjenjuju leksikografski stil pisanja. Tekstualni sadržaji donose se sažetim, jasnim, taksativnim, nabrajalačkim, ponegdje statističkim stilom s mnogo brojčanih podataka. Premda je takav stil ponekad suhoparan i teško čitljiv, njegovom primjenom mogućnost subjektivnih interpretacija svedena je na minimum, što se onda pretvara u njegovu prednost. ${ }^{18}$

\subsection{Zavodski atlasi i geografsko znanje}

Zavodski atlasi imaju i neke nedostatke, koji se prije svega očituju u proizvodnji i održavanju stereotipa o geografiji. Iz njih se stječe dojam da je geografija:

a) zapravo fizička geografija, osobito u starijim atlasima. U obrazloženju strukture država i ovisnih područja u ${ }^{1} \mathrm{AS}$ (VII) navodi se da su: »sve ostale države i teritoriji poređani alfabetskim redom, po shemi: geografski prikaz (građa i reljef, klima, vode, biljni pokrov), podatci o stanovništvu, političko i državno uređenje, administrativna podjela po tablicama, šef države, glavni grad, privreda, trgovina, saobraćaj i novac«, iz čega proizlazi da su geografski elementi prostora samo oni fizičkogeografski, dok su društvenogeografski izuzeti iz geografskoga opisivanja. Takvo je shvaćanje geografije i predmeta njezina proučavanja vrlo tradicionalno i stoga odavno napušteno pa se u kasnijim atlasima pod geografskom obradom smatraju i podatci o društvenim elementima prostora. Ipak, moguće je da se zbog duge tradicije i raširenosti zavodskih atlasa nepovoljno tradicionalno poimanje geografije $u$ javnosti održalo do danas.

b) deskriptivna, taksativna i duboko statistički utemeljena znanost koja se bavi isključivo promatranjem, opisivanjem i mjerenjem prostora, dakle njegovom kvantitativnom analizom, bez ikakve sinteze. Ako sinteza postoji, ona je regionalno, a ne problemski/tematski utemeljena. $\mathrm{O}$ geografiji se stoga može steći dojam kao o zanimljivoj, ali površnoj znanosti koja samo konstatira postojanje nekoga geografskoga objekta ili pojave te ga kvantitativno opisuje (Crljenko, Klemenčić 2017). Takvo je shvaćanje djelomično rezultat »ladičarskoga« nabrajanja nepovezanih činjenica o prostornim jedinicama po zadanoj strukturi - obilato potkrijepljenoga brojkama i grafičkim prilozima, bez tumačenja uzročno-posljedičnih veza među pojavama i procesima u prostoru - koje je zastupljeno u mnogim enciklopedičkim izdanjima. Djelomično je rezultat i manjkavosti unutar same geografije, odnosno nepostojanja

18 Krajnje sažet, gotovo leksikonski, stil pisanja svojstven je AS21./03. U atlasima AS80, ZA85, AS2000/98, EAS97, VAS02, VOAS04, ATL07 i AS08 stil je više ili manje popularnoznanstveni. To znači da je opušteniji, s mnogo atributa i opisa. Takav stil nerijetko prate kraći tekstovi, često smješteni uz male ilustracije kao njihovi opisi ili su u izdvojenim tekstualnim okvirima, najčešće o pojedinim temama, podijeljeni u nekoliko poglavlja i potpoglavlja te popraćeni mnogim tematskim kartama/skicama i ilustracijama. 
mnogih vrsta podataka za sva područja svijeta (pa da bi se zadržala dosljednost, moraju se rabiti samo podatci provedivi svugdje), kao i činjenice da su neki dijelovi svijeta u velikoj mjeri istraženi, dok su drugi znatno slabije pokriveni relevantnim podatcima.

\section{Zaključak}

U radu predstavljeno istraživanje potvrdilo je pretpostavku da je značenje zavodskoga atlasa svijeta u hrvatskoj atlasnoj kartografiji iznimno, što se očituje u njegovim posebnostima u odnosu na druge atlase. Zavodski atlas prikazuje svijet iz domaće perspektive, odražava visoku stručnost u obradi sadržaja primjenom načela obuhvatnosti i dosljednosti, sadržava pojačanu tekstualnu sastavnicu, postavlja norme u pisanju geografskih imena iz stranih jezika, predočuje vlastite karte i primjenjuje leksikografski stil pisanja. Poput većine drugih atlasa, slijedi sve enciklopedičke principe. Predmetom obrade inherentno je sveobuhvatan, u predstavljanju prostornih jedinica konsolidiran (dosljedan), u obradi sadržaja sažet, točan, organiziran (slijedi zadanu strukturu) i ažuran, u odabiru sadržaja vjerodostojan i relevantan (uglavnom se svugdje navode iste, najvažnije vrste podataka), a u obradi tekstualnih sadržaja teži maksimalnoj objektivnosti (utemeljen je činjenično, a ne ideološki). Kao i drugi atlasi, neobjektivan je samo u koncepciji jer predstavlja svijet iz vlastite optike. Unatoč tome što su mu glavni nedostatci upravo u segmentu predstavljanja geografskih znanja, može se zaključiti da je zavodski atlas ispunio svoju ulogu kao mjerodavno vrelo tih znanja već 60 godina. Kako bi se odmaknuo od tradicionalnog statističko-deskriptivnoga pristupa, u sljedećim bi se izdanjima trebao pokušati pronaći model iznošenja uzročno-posljedično povezanih geografskih informacija, čak i ako je to na štetu njihova mnoštva. U suvremenom dobu lako dostupnih podataka, težište bi novoga atlasa trebalo biti na tumačenju, a ne pukoj konstataciji podataka, ne gubeći pritom na njihovoj točnosti i vjerodostojnosti. 


\section{LITERATURA}

Crljenko, Ivana (2019). »Otvorena pitanja o pisanju i uporabi hrvatskih egzonima na kartama« / »Open Questions on Writing and the Use of Croatian Exonyms on Maps«. Kartografija i geoinformacije, 18 (31), 26-59.

Crljenko, Ivana, Klemenčić, Mladen (2011). »Geografska imena u leksikografskim izdanjima«. U: Zbornik radova s Prvoga nacionalnog znanstvenog savjetovanja o geografskim imenima, 105110. Zadar, Sveučilište u Zadru i Hrvatsko geografsko društvo.

Crljenko, Ivana, Klemenčić, Mladen (2017). »Geografija i geografi u Leksikografskom zavodu Miroslav Krleža«. Studia lexicographica, 21 (11), 113-122.

Faričić, Josip (2004). »Atlas svijeta za 21. stoljeće« / »The 21st Century World Atlas« - prikaz. Kartografija i geoinformacije, 3, 108-109.

Feletar, Dragutin (1989). »Atlas svijeta« - prikaz. Geografski glasnik, 51, 250-251.

Jecić, Zdenko (2013). »Enciklopedički koncept u mrežnom okruženju«. Studia lexicographica, 13 (7), 99-115.

Jordan, Peter (1995). »Hrvatska - nova država predstavlja se Atlasom«. Radovi Leksikografskoga zavoda Miroslav Krleža, 4, 223-230.

Klemenčić, Mladen (1993). »O zamisli i sadržaju Atlasa (nove) Europe«. Radovi Leksikografskoga zavoda Miroslav Krleža, 3, 15-22.

Klemenčić, Mladen (2013). »Atlasna sastavnica enciklopedike«. Studia lexicographica, 13 (7), 89-97.

Klemenčić, Mladen, Nikolić, Borna (1987). »Prilog raspravi o položaju i problemima geografije u leksikografiji«. Geografski glasnik, 49 (1), 63-66.

Klemenčić, Mladen, Richter-Novosel, Željka (2001). »Kartografija i kartografi u Leksikografskom zavodu«. Radovi Leksikografskoga zavoda Miroslav Krleža, 10, 305-311.

Klemenčić, Mladen, Richter-Novosel, Željka (2008). »Cartography in the Lexicographic Institute« / „Kartografija u Leksikografskom zavodu«. Kartografija i geoinformacije, 7 (10), 86-95.

Klobučar Srbić, Iva (2012). »Bibliografija izdanja Leksikografskoga zavoda Miroslav Krleža (19502013)«. Studia lexicographica, 10-11 (6), 5-66.

Resolutions on exonyms, http://ungegn.zrcsazu.si/Portals/7/WGE\%20Activities/Resolutions_on_ exonyms.pdf (24. XII. 2020).

Richter, Željka (1996). »Atlasna kartografija u Hrvatskoj«. Geodetski list, izvanredni broj, 50, 46-50.

\section{IZVORI}

Zavodski atlasi:

Atlas svijeta, ${ }^{1}$ 1961., Leksikografski zavod FNRJ, Zagreb. ('AS)

Atlas svijeta, ${ }^{2} 1963$. , Jugoslavenski leksikografski zavod, Zagreb. ( ${ }^{2}$ AS)

Atlas svijeta, ${ }^{3} 1966$. ., Jugoslavenski leksikografski zavod, Zagreb. ('AS)

Atlas svijeta, ${ }^{4} 1969$., Jugoslavenski leksikografski zavod, Zagreb. ( ${ }^{4}$ AS)

Atlas svijeta, ${ }^{5} 1974$. ., Jugoslavenski leksikografski zavod, Zagreb. ('AS)

Atlas svijeta, ${ }^{6} 1988$., Jugoslavenski leksikografski zavod Miroslav Krleža, Zagreb. ( ${ }^{6}$ AS)

Atlas svijeta, ${ }^{72} 2006$., Leksikografski zavod Miroslav Krleža, Zagreb. ( $\left.{ }^{7} \mathrm{AS}\right)$ 
Atlasi drugih nakladnika:

Veliki atlas svijeta, 1974., Prosveta - Mladinska knjiga, Beograd - Ljubljana. (VAS74)

Atlas svijeta: novi pogled na Zemlju, ${ }^{21980}$., Sveučilišna naklada Liber, Zagreb. (AS80)

Zemljopisni atlas: svijet u brojkama, zemlja i svemir, države svijeta, 1985., Mladinska knjiga, Ljubljana. (ZA85)

Enciklopedijski atlas svijeta, 1997., Extrade, Zagreb. (EAS97)

Atlas svijeta 2000: novi pogled na Zemlju, 1998., Mozaik knjiga. Zagreb. (AS2000/98)

Veliki atlas svijeta, 2002., Leo-commerce. Zagreb. (VAS02)

Atlas svijeta za 21. stoljeće, 2003., Naklada Fran d.o.o., Zagreb. (AS21./03)

Veliki obiteljski atlas svijeta, 2004., Naklada Ljevak i Monde Neuf., Zagreb. (VOAS04)

Atlantika: veliki satelitski atlas svijeta, 2007., Mozaik knjiga, Zagreb. (ATL07)

Atlas svijeta, 2008., Mozaik knjiga. Zagreb. (AS08)

\title{
THE SIGNIFICANCE OF THE MIROSLAV KRLEŽA INSTITUTE OF LEXICOGRAPHY'S WORLD ATLAS IN CROATIAN ATLAS CARTOGRAPHY
}

\author{
Ivana Crljenko \\ The Miroslav Krleža Institute of Lexicography, Zagreb \\ ivana.crljenko@lzmk.hr
}

\begin{abstract}
The Miroslav Krleža Institute of Lexicography has been publishing general purpose geographical atlases since the 1960s. The most prominent of these is the World Atlas, which has seen seven editions, edited by several editors-in-chief, who mostly retained the initial concept of the atlas, but introduced new editorial ideas and styles. It is the only wholly Croatian world atlas, commercially among the most successful publications of the Institute of Lexicography, and one of the most widespread atlases in Croatia. Therefore, it is presumed that it was of exceptionally high significance in the production of geographical world atlases in Croatia. The goal of this paper is to show whether this presumption is justified. An analysis of some characteristics (ideas, specificities, atlas structure and chapters, maps, approaches, writing style) of the Institute's and selected translated world atlases in the period from the printing of the first (1961) to the last Institute's atlas (2008) was made, and the results were compared in order to achieve the goals of this research: a) identify the similarities and differences (specificities) of the Institute's atlas in regard to atlases of other publishers, b) estimate the influence of the Institute's atlas in spreading geographical knowledge, and c) determine its significance in Croatian atlas cartography. The research results point towards the exceptional importance of the Institute's atlas, which stems from its specificities. It stands out among the others because it depicts the world from a Croatian perspective, reflects a high level of professionalism in content processing by applying the principles of comprehensiveness and consistence, contains a strong textual component, sets norms in writing geographical names from foreign languages, presents its own maps, and applies a lexicographical writing style.
\end{abstract}

Keywords: world atlases; The Miroslav Krleža Institute of Lexicography; maps; toponyms 